\title{
A checklist of Plateros Bourgeois, 1879 from Africa, with description of new species (Coleoptera: Lycidae)
}

\section{Список Plateros Bourgeois, 1879 из Африки, с описанием новых видов (Coleoptera: Lycidae)}

\author{
Sergey V. Kazantsev \\ С.В. Казанцев
}

Insect Centre, Donetskaya 13-326, Moscow 109651, Russia.

Инсект-центр, ул. Донецкая 13-326, Москва 109651, Россия. E-mail: kazantss@mail.ru

KEY WORDS: Coleoptera, Lycidae, new species, Afrotropical region.

КЛЮЧЕВЫЕ СЛОВА: Coleoptera, Lycidae, новые виды, Афротропическая область.

ABSTRACT. Sixteen new species of net-winged beetles of the genus Plateros Bourgeois, 1879: $P$. amaniensis, $P$. aurifer, $P$. dewittei, $P$. eburneus, $P$. gorongosus, $P$. guttifer, $P$. hamifer, $P$. hamulifer, $P$. hippocampus, $P$. kuehnei, $P$. morogoroensis, $P$. nyungwensis, $P$. odzalaensis, $P$. ogovensis, $P$. subulifer and $P$. uluguruensis spp.n. - are described from Afrotropical region. A new replacement name Plateros breveapis nom.n. is proposed for Plateros breveapicalis (Pic, 1938), nec Plateros breveapicalis (Pic, 1931). Plateros burgeoni (Pic, 1924), P. curtus (Bourgeois, 1905) and $P$. nigricauda (Bourgeois, 1910) are illustrated. A checklist of Plateros species of the Afrotropical region is provided.

How to cite this article: Kazantsev S.V. 2018. A checklist of Plateros Bourgeois, 1879 from Africa, with description of new species (Coleoptera: Lycidae) // Russian Entomol. J. Vol.27. No.1. P.19-32. doi: 10.15298/ rusentj.27.1.04

РЕЗЮМЕ. Из Афротропическогй области описывается шестнадцать новых видов жуков-краснокрылов рода Plateros Bourgeois, 1879: P. amaniensis, $P$. aurifer, $P$. dewittei, $P$. eburneus, $P$. gorongosus, $P$. guttifer, $P$. hamifer, $P$. hamulifer, $P$. hippocampus, $P$. kuehnei, P. morogoroensis, $P$. nyungwensis, $P$. odzalaensis, $P$. ogovensis, $P$. subulifer и $P$. uluguruensis spp.n. Предлагается замещающее название Plateros breveapis nom.n. для Plateros breveapicalis (Pic, 1938), nec Plateros breveapicalis (Pic, 1931). Приводятся иллюстрации Plateros burgeoni (Pic, 1924), $P$. curtus (Bourgeois, 1905) и P. nigricauda (Bourgeois, 1910) и список видов Plateros Афротропическиой области.

\section{Introduction}

The lycid genus Plateros Bourgeois, 1879 is the most widespread and species-rich in the family, represented in all biogeographical regions, except western
Palaearctic, the Greater Antilles, Madagascar, New Zealand and Melanesia/Polynesia [Kleine, 1933; Kazantsev, 2011].

First African species of Plateros were described as Planeteros Gorham, 1883 in the 1880s [Gorham, 1883; Bourgeois, 1883; Fairmaire, 1887] and currently there are 53 valid species level Plateros taxa from the Afrotropical region [Kazantsev, 1997; 2000; 2005; 2011].

An opportunity to study the Lycidae collections of the Institut Royal de Sciences naturelles de Belgique, Erfurt Naturkundemuseum, Zoologische Staatssammlung München, Transvaal Museum of Natural History and Moscow Insect Centre makes it possible to further contribute to the knowledge of the genus of this region. In the present paper Plateros burgeoni (Pic, 1924), P. curtus (Bourgeois, 1905) and P. nigricauda (Bourgeois, 1910) are illustrated, sixteen new species are described, and a list of Plateros of the Afrotropical region is provided.

\section{Material and Methods}

The studied specimens were pinned or glued on cardboard plates. For a detailed examination they were relaxed in water; then the detached ultimate abdominal segments were treated for several hours in $10 \% \mathrm{KOH}$ at room temperature, the extracted genitalia were placed in microvials with glycerin for photography, then glued back on cardboard plates.

MSP-1 zoom stereoscopic dissecing microscope with $\mathrm{x} 8-\mathrm{x} 80$ magnification range was used. Photographs were taken with Canon EOS 6D camera and Canon MP-E $65 \mathrm{~mm}$ lens.

The following acronyms are used in the paper: ICM Insect Center, Moscow; IRSN — Institut Royal de Sciences naturelles de Belgique, Bruxelles; NME - Naturkundemuseum, Erfurt; TMNH - Transvaal Museum of Natural History, Pretoria; ZSM - Zoologische Staatssammlung, München. 
Taxonomy

Plateros Bourgeois, 1879

Plateros Bourgeois, 1879: xix. Type species: Eros brasiliensis Lucas, 1857 (subsequsent designation by Zaragoza, 1999).

= Planeteros Gorham, 1883: 591. Type species: Planeteros ochropterus Gorham, 1883: 591 (by monotypy).

\section{Plateros burgeoni (Pic, 1924)}

Figs $1-2$.

Planeteros sibutensis var. burgeoni Pic, 1924: 439.

MATERIAL: $0^{7}$, S Africa, Zululand, St. Lucia, Mission Rk., $28.22^{\circ} \mathrm{S}, 32.25^{\circ} \mathrm{E}$, UV light, 9.XII.1975, Endrödy-Younga leg.; $0^{7}$, S Africa, Natal, St. Lucia, light, 31.XII.1991, P. Klimaszewski leg. (ICM and TMNH).

DISTRIBUTION. East of the Democratic Republic of the Congo and South Africa (Zululand/Natal). New record for South Africa.

Plateros chirindanus (Kleine, 1933)

Planeteros chirindanus Kleine, 1933: 15.

Planeteros zairicus Kasantsev, 1997: 15

MATERIAL: $0^{7}$, Tanganyika, Morogoro, II.1963, G. Heinrich leg. (ZSM).

DISTRIBUTION. Congo (Zaire), East Africa ('Nyassa', Tanzania). New record for Tanzania.
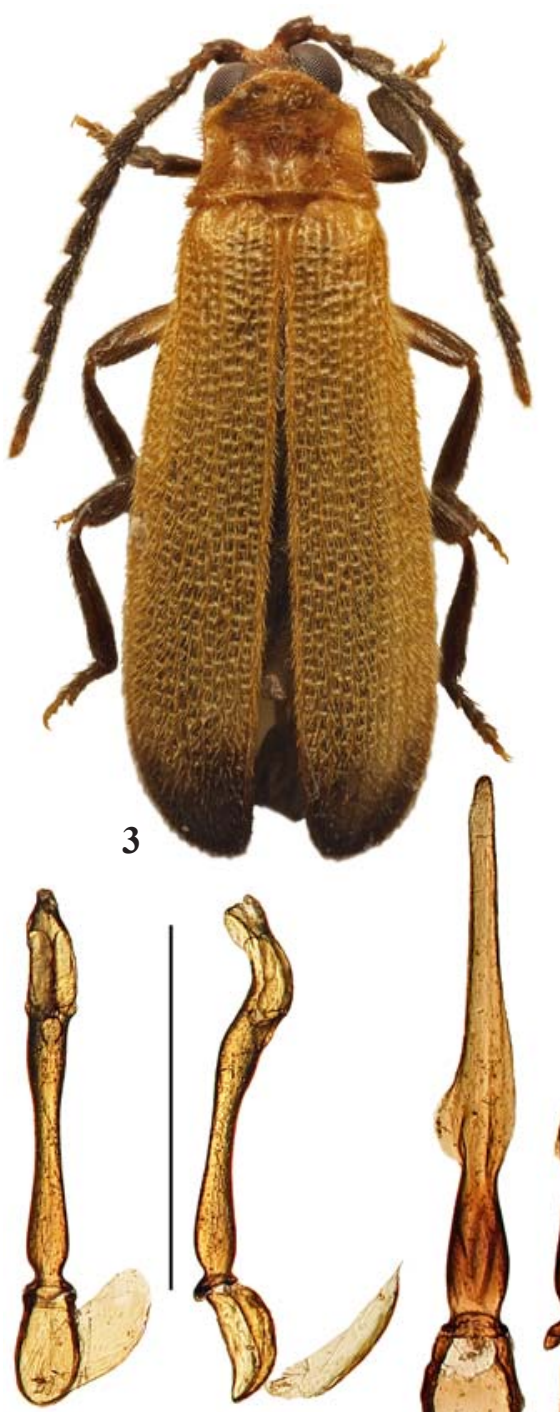

4

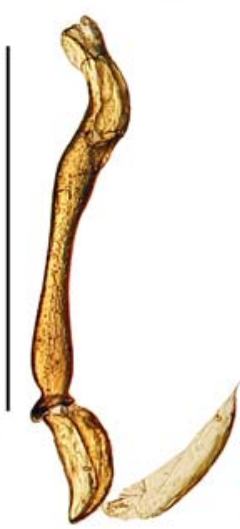

5
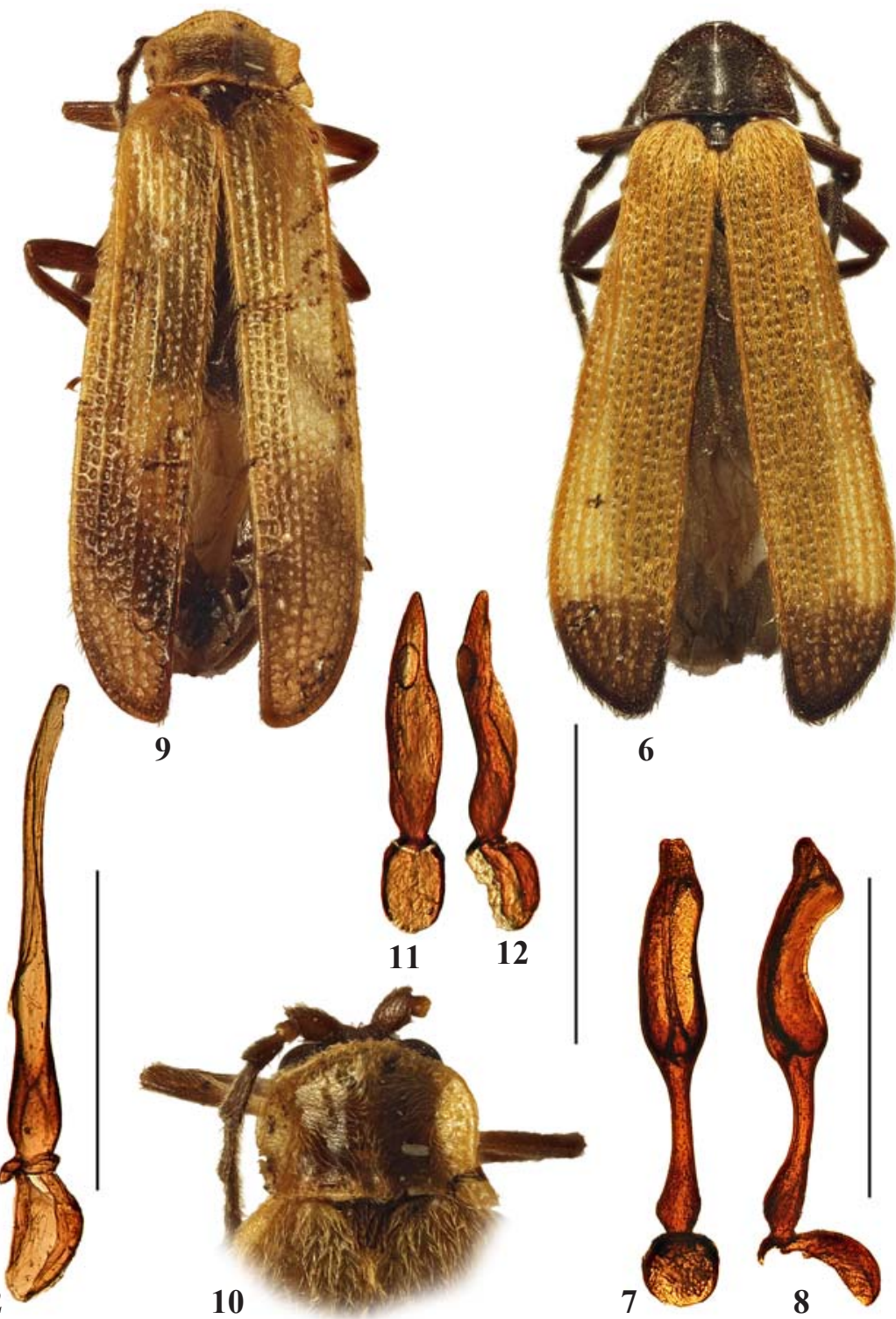

Figs 1-12. General view and details of Plateros, males: 1-2 - P. burgeoni; 3-5 - P. curtus; 6-8 - P. nigricauda; 9-12 - P. amaniensis sp.n.; 9-12 - holotype; 3, 6, 9- general view; 10 - head and pronotum; 1-2, 4-5, 7-8, 11-12 - aedeagus; 3, 6, 9-10 - dorsal aspect; $1,4,7,11$ - ventral aspect; 2, 5, 8, 12 - lateral aspect. Scale bars: $1.0 \mathrm{~mm}$.

Рис. 1-12. Общий вид и детали стоения Plateros, самцы: 1-2 - P. burgeoni; 3-5 - P. curtus; 6-8 - P. nigricauda; 9-12 - P. amaniensis sp.n.; 9-12 - голотип; 3, 6, 9- общий вид; 10 - голова и переднеспинка; 1-2, 4-5, 7-8 - эдеагус; 3, 6, 9-10 - сверху; $1,4,7,11$ - снизу; 2, 5, 8, 12 - сбоку. Масштабные линейки: 1.0 мм. 
Plateros curtus (Bourgeois, 1905)

Figs 3-5.

Planeteros curtus Bourgeois, 1905: 34.

MATERIAL: $0^{7}+$, E Gabon: Ogooué-Ivindo Prov., 5-9 km SW Makokou, Ivindo N.P., Ipassa Research Station, $0^{\circ} 30^{\prime} 52^{\prime \prime} \mathrm{N}, 12^{\circ} 48^{\prime} 51^{\prime \prime}$ E, 480-540 m, edge of secondary lowland rainforest, white light trap in canopy, 24-25.VI.2016, D. Telnov leg. (ICM and DTPC).

DISTRIBUTION. Distributed in West Africa (Equatorial Guinea, Democratic Republic of the Congo, Gabon). New record for Gabon.

\section{Plateros nigricauda (Bourgeois, 1910)}

Figs 6-8.

Planeteros nigricauda Bourgeois, 1910: 118.

MATERIAL: $\sigma^{7}$, Tanzania, S slope of Mt Meru, $10 \mathrm{~km} \mathrm{~N}$ Arusha, ca. $2600 \mathrm{~m}, 15 . \mathrm{VII} .1995$, Ward \& Greswell leg. (ICM).

DISTRIBUTION. Tanzania (Mt Meru).

\section{Plateros amaniensis Kazantsev, sp.n.} Figs 9-12.

MATERIAL: Holotype, $0^{7}$, Tanzania: E Usambara, Amani N.R., $5.05^{\circ} \mathrm{S}, 38.40^{\circ} \mathrm{E}, 1000 \mathrm{~m}, 20-22 . \mathrm{I} .2010$, M. Mityukhin leg. (ICM).

DESCRIPTION. Male. Dark brown to black; pronotum, except at disk, and elytra, except at distal third, testaceous; antennomere 2, pro- and mesotrochanters and pro- and mesofemurs in proximal half light brown.

Vertex shining, with conspicuous transverse impression behind antennal prominence. Eyes relatively small, interocular distance ca. 1.4 times greater than eye diameter. Labrum small, transverse, slightly emarginate anteriorly. Palps slender, ultimate palpomeres elongate, almost parallel-sided, distally oblique. Antennal sockets separated by minute lamina Antennae dentate, reaching over elytral half; antennomere 3 ca. 2.9 times longer than antennomere 2 and ca. 1.5 times shorter than antennomere 4; antennomeres 3-11 with short sub-erect pubescence (Figs 9-10).

Pronotum transverse, ca. 1.6 times as wide as long, almost basally and noticeably triangularly produced forward anteriorly, with almost parallel sides, produced postero-laterally acute posterior and widely rounded anterior angles. Mesothoracic spiracle small, hoodless, not protruding beyond coxa. Scutellum elongate, slightly narrowing distally, inconspicuously emarginate at apex (Fig. 10).

Elytra long, ca. 3 times longer than wide at humeri, parallel-sided, with primary costa 4 conspicuously more elevated in proximal two thirds; all interstices with double rows of small roundish cells; pubescence short and semierect (Fig. 9). Tibiae and femoris straight, narrow; tarsomeres 3-4 slightly widened, tarsomeres 1-2 with apical plantar pad.

Aedeagus slightly asymmetric, with elongate, robust, tapering distally and slightly bent both in dorsal and lateral views median lobe, with oval opening distal third; phallobase constituting ca 0.3 length of median lobe (Figs 11-12).

Female. Unknown.

Length: $5.8 \mathrm{~mm}$. Width (humerally): $1.7 \mathrm{~mm}$.

ETYMOLOGY. The new species is named after its type locality.

DIAGNOSIS. Plateros amaniensis sp.n. is quite different from all congenerics in having the robust, tapering distally median lobe of the aedeagus (Figs 10-12).

REMARK. Tips of antennae in the unique holotype are missing.

DISTRIBUTION. East Africa (eastern Tanzania).

\section{Plateros aurifer Kazantsev, sp.n.}

Figs 13-15.

MATERIAL: Holotype, $\sigma^{7}$, SW Ghana, Ankasa For. Res., primary rainforest, 40-90 m, 17-25.VII.2017, Sv. Kurbatova leg. (ICM).

DESCRIPTION. Male. Brownish; pronotum, scutellum, elytra, trochanters and femurs testaceous; antennomeres 10 11 orange testaceous.

Vertex shining, with conspicuous round impression behind antennal prominence. Eyes large, interocular distance ca. 1.8 times shorter than eye diameter. Labrum small, transverse. Palps slender, ultimate palpomeres elongate, slightly widening distally. Antennal sockets separated by minute lamina. Antennae feebly dentate, attaining to elytral two thirds; antennomere $3 \mathrm{ca}$. 1.5 times longer than antennomere 2 and ca. 1.8 times shorter than antennomere 4 ; antennomeres 3-11 with short semi-erect pubescence (Fig. 16).

Pronotum transverse, ca. 1.7 times as wide as long, trapezoidal, almost straight basally and conspicuously triangularly produced forward anteriorly, with almost straight sides, acute posterior and conspicuous blunt anterior angles; medially with short obscure longitudinal impression posteriorly. Mesothoracic spiracle small, hoodless, not protruding beyond coxa. Scutellum transverse, narrowing distally, broadly rounded at apex (Fig. 16).

Elytra long, ca. 3.2 times longer than wide at humeri, slightly widening distally, with slender, equally developed primary costae, only primary costa 4 evidently stouter in proximal forth; all interstices with double rows of small roundish cells; pubescence dense, short and semi-erect. Tibiae and femoris straight, moderately broad; tarsomere 4 slightly widened, tarsomeres 1-2 with apical plantar pad (Fig. 16).

Aedeagus slightly asymmetric, with long, straight, relatively narrow median lobe, slightly widened apically; phallobase constituting ca 0.25 length of median lobe (Figs 17-18).

Female. Unknown.

Length: $5.0 \mathrm{~mm}$. Width (humerally): $1.2 \mathrm{~mm}$.

ETYMOLOGY. The name of the new species is derived from the Latin for «gold-bearing», alluding to its coloration and vestiture.

DIAGNOSIS. Plateros aurifer sp.n. resembles $P$. curtus, also from West Africa, but may be distinguished by the uniformly testaceous elytra, orange testaceous antennomeres $10-11$, as well as by the straight and more robust median lobe of the aedeagus (Figs 16-18).

DISTRIBUTION. West Africa (Ghana).

\section{Plateros dewittei Kazantsev, sp.n. Figs 16-18.}

MATERIAL: Holotype, $O^{7}$, Congo belge: P.N.U., entre R. BuyeBala R. Katongo, 1750 m, 27.IX.1948, Mis. G.F. de Witte (1867a) (IRSN).

DESCRIPTION. Male. Black; elytra, except at distal fifth, bright testaceous.

Vertex shining, with two small round impressions behind antennal prominence. Eyes relatively small, interocular distance ca. 1.5 times greater than eye diameter. Labrum small, transverse, rounded anteriorly. Palps slender, ultimate palpomeres slightly longer than wide, slightly widening distally. Antennal sockets separated by narrow lamina. Antennae dentate, attaining to elytral half; antennomere $3 \mathrm{ca}$. 2.5 times longer than antennomere 2 and ca. 1.5 times shorter than antennomere 4; antennomeres 3-11 with short erect pubescence (Fig. 16).

Pronotum transverse, ca. 1.6 times as wide as long, bisinuate basally and rounded anteriorly, with almost parallel 
sides, long acute posterior and blunt anterior angles; medially with obscure longitudinal impression posteriorly and short median rib anteriorly. Mesothoracic spiracle small, hoodless, not protruding beyond coxa. Scutellum subquadrate, parallel-sided, slightly emarginate at apex (Fig. 16).

Elytra long, ca. 3.6 times longer than wide at humeri, slightly widening distally, with slender, equally developed primary costae; all interstices with double rows of small, mostly square cells; pubescence dense, short and semi-erect. Tibiae and femoris straight, moderately broad; tarsomeres 3 and 4 slightly widened, tarsomeres 1-2 with apical plantar pad (Fig. 16).

Aedeagus almost symmetric, with very long, straight, narrow median lobe, noticeably widened apically; phallobase constituting ca 0.2 length of median lobe (Figs 17-18).

Female. Unknown.

Length: $6.5-6.8 \mathrm{~mm}$. Width (humerally): $1.7-1.8 \mathrm{~mm}$.

ETYMOLOGY. The new species is after the collector of the unique holotype.
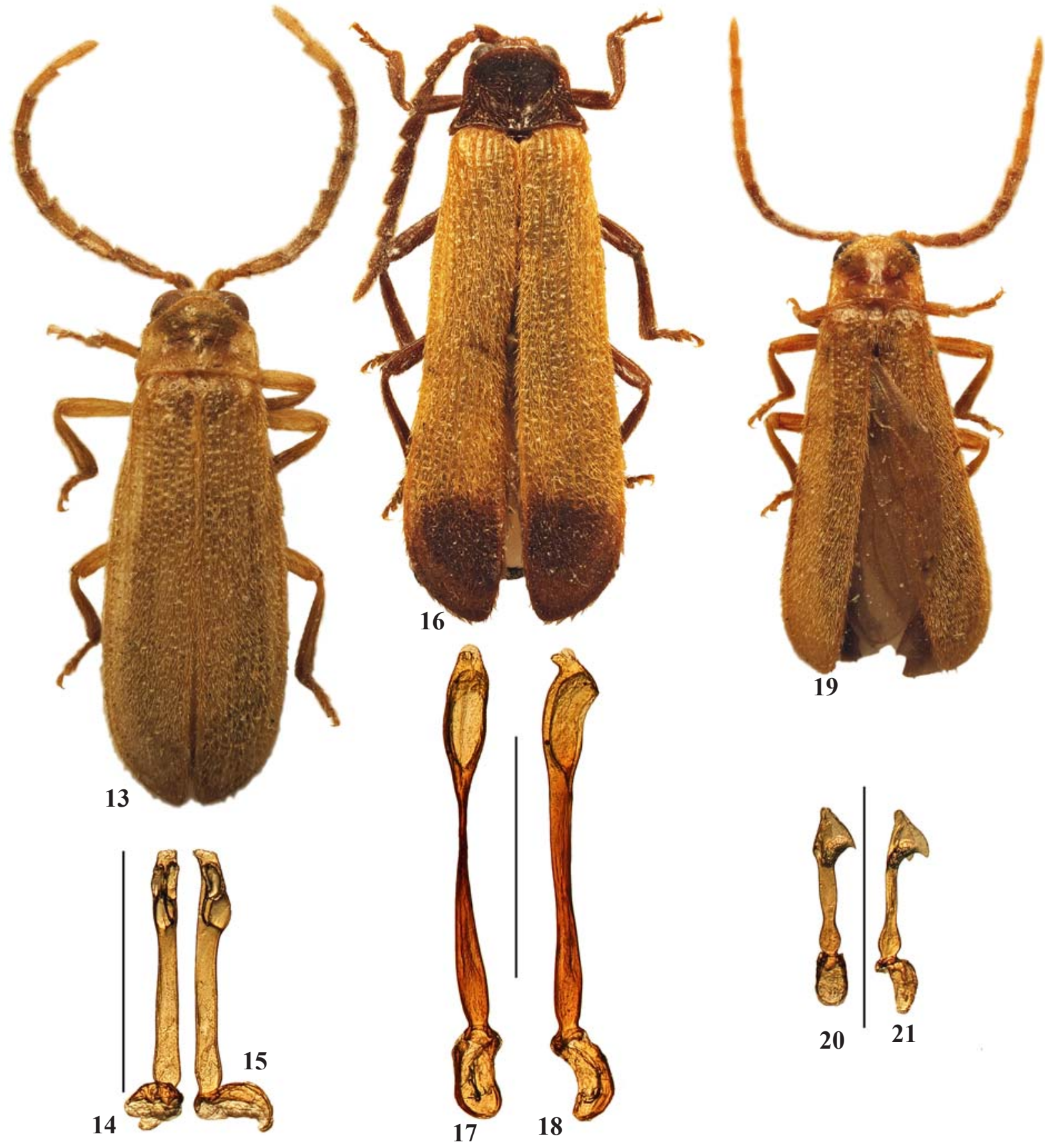

Figs 13-21. General view and aedeagi of Plateros, holotype males: 13-15 - P. aurifer sp.n.; 16-18 - P. dewittei sp.n.; 19-21 - P. eburneus sp.n.; 13, 16, 19 - general view; 14-15, 17-18, 20-21 — aedeagus; 13, 16, 19 - dorsal aspect; 14, 17, 20 - ventral aspect; 15 , 18,21 - lateral aspect. Scale bars: $1.0 \mathrm{~mm}$.

Рис. 13-21. Общий вид и детали строения Plateros, голотипы, самцы: 13-15 - P. aurifer sp.n.; 16-18 - P. dewittei sp.n.; 1921 - P. eburneus sp.n.; 13, 16, 19 - общий вид; 14-15, 17-18, 20-21 - эдеагус; 13, 16,19 - сверху; 14, 17, 20 - снизу; 15, 18, 21 - сбоку. Масштабные линейки: 1.0 мм. 
DIAGNOSIS. In the shape of the aedeagus Plateros dewittei sp.n. somewhat resembles $P$. nigricauda (Figs 6-8), from Mount Meru, Tanzania, but may be distinguished by the straighter, slenderer and less widened apically median lobe of the aedeagus (Figs 17-18).

DISTRIBUTION. West Africa (Democratic Republic of the Congo/formerly known as Belgian Congo).

\section{Plateros eburneus Kazantsev, sp.n. Figs 19-21.}

MATERIAL: Holotype, $\sigma^{7}$, Cote d'Ivoire, Abidjan, Reserve de Banco, 9-10.IX.1997, M. Leroux (ICM).

DESCRIPTION. Male. Testaceous; antennomeres 3-7, meso- and metaventrite, tibiae, tarsi and abdomen brown.

Vertex shining, with median excavation between eyes. Eyes large, interocular distance ca. 1.2 times greater than eye diameter. Labrum small, transverse. Palps slender, ultimate palpomeres elongate, almost parallel-sided, flattened and glabrous distally. Antennal sockets separated by minute lamina. Antennae feebly dentate, flattened, attaining to elytral two thirds; antennomere 3 ca. 1.8 times longer than antennomere 2 and ca. 1.6 times shorter than antennomere 4; antennomeres 3-11 with short erect pubescence (Fig. 19).

Pronotum transverse, ca. 1.4 times as wide as long, slightly trapezoidal, straight basally and produced forward and rounded anteriorly, with straight sides, acute posterior and broadly rounded anterior angles; medially with obscure longitudinal impression posteriorly. Mesothoracic spiracle small, hoodless, not protruding beyond coxa. Scutellum subquadrate, almost parallel-sided, slightly emarginate at apex (Fig. 19).
Elytra long, ca. 3.2 times longer than wide at humeri, parallel-sided, with slender, equally developed primary costae; all interstices with double rows of small subquadrate cells; dense pubescence short and semi-erect. Tibiae and femoris straight, narrow; tarsomeres 1-4 narrow, tarsomere 4 bilobed, tarsomeres 1-2 with minute apical plantar pad (Fig. 19).

Aedeagus almost symmetric, with elongate, relatively robust median lobe, provided with large and curved inwardly paired distal hooks; phallobase constituting ca 0.3 length of median lobe (Figs 20-21).

Female. Unknown.

Length: $4.8 \mathrm{~mm}$. Width (humerally): $1.1 \mathrm{~mm}$.

ETYMOLOGY. The name of the new species is derived from the Latin for «ivory», alluding to its country of origin.

DIAGNOSIS. Plateros eburneus sp.n. seems to be related to $P$. petrovi (Kazantsev, 2000), from Equatorial Guinea, separable by the more robust median lobe of the aedeagus, with relatively larger and less curved inwardly paired distal hooks.

DISTRIBUTION. West Africa (Cote d'Ivoire).

\section{Plateros guttifer Kazantsev, sp.n.}

Figs 22-26.

MATERIAL: Holotype, $\sigma^{7}$, SW Rwanda, Nyungwe N.P., 1800 2000 m, 3-16.VII.2014, Sv. Kurbatova leg. (ICM); paratypes, 3 우, same label; paratypes, $1 \mathrm{O}^{7}$ and 2 ${ }^{\circ}$, SW Rwanda, Nyungwe N.P., 2300-2500 m, 3-16.VII.2014, Sv. Kurbatova leg. (ICM).

DESCRIPTION. Male. Black; elytra ochre.

Vertex shining, almost flat behind antennal prominence. Eyes small, interocular distance ca. 1.4 times greater than eye diameter. Labrum small, transverse, rectangular, inconspicuously emarginate medially. Palps slender, ultimate palpomer-

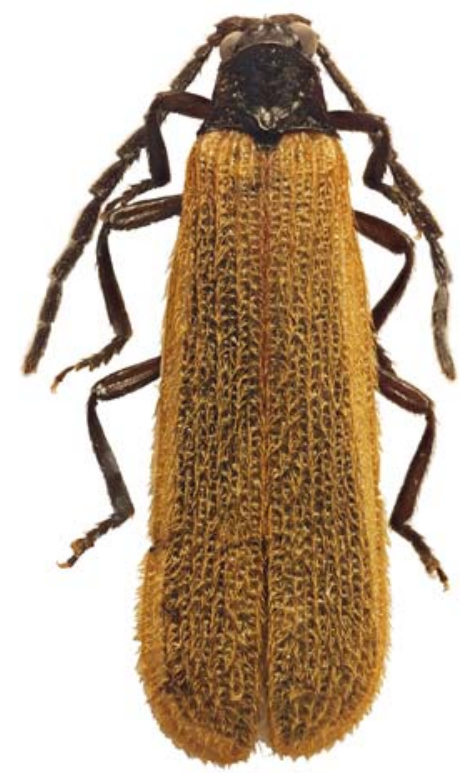

22

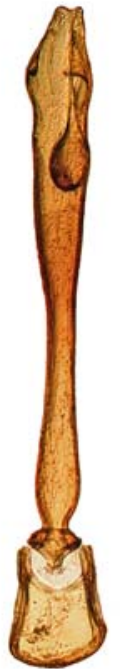

23
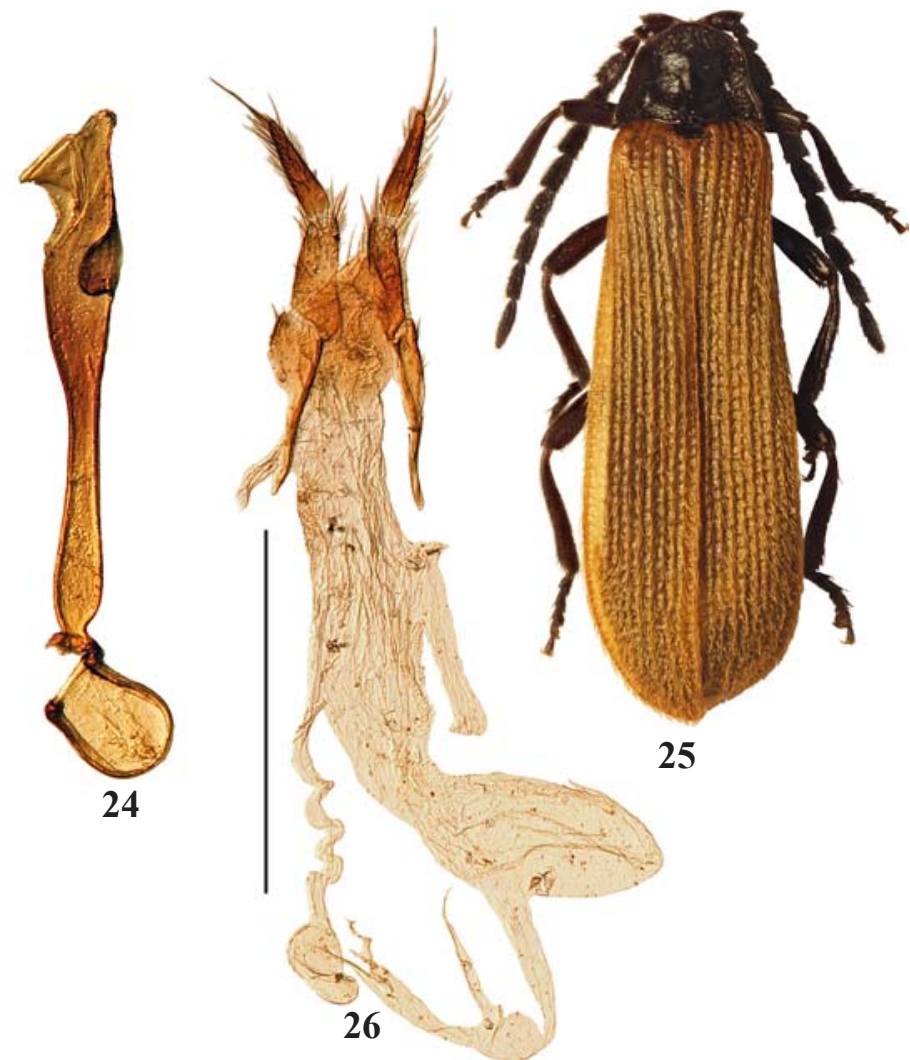

Figs 22-26. General view and details of Plateros guttifer sp.n.: 22-24 - holotype male; 25-26 - paratype female; 22,25 - general view; 23-24 - aedeagus; 26 - female genitalia; 22, 25 - dorsal aspect; 23,26 - ventral aspect; 24 - lateral aspect. Scale bars: $1.0 \mathrm{~mm}$.

Рис. 22-26. Общий вид и детали строения Plateros guttifer sp.n.: 22-24 — голотип, самец; 25-26 — паратип, самка; 22, 25 общий вид; 23-24 - эдеагус; 26 - женские гениталии; 22, 25 - сверху; 23, 26 - снизу; 24 - сбоку. Масштабные линейки: 1.0 мм. 
es elongate, nearly parallel-sided, flattened and glabrous at apex. Antennal sockets separated by minute lamina. Antennae feebly dentate, slightly reaching over elytral half; antennomere $3 \mathrm{ca}$. 1.2 times longer than antennomere 2 and ca. 2.2 times shorter than antennomere 4; antennomeres 3-11 with short erect pubescence (Fig. 22).

Pronotum transverse, ca. 1.5 times as wide as long, feebly bisinuate basally and rounded anteriorly, with straight sides, acute posterior and rounded blunt anterior angles; medially with obscure longitudinal impression posteriorly and short median rib anteriorly. Mesothoracic spiracle small, hoodless, not protruding beyond coxa. Scutellum transverse, narrowing distally, feebly emarginate at apex (Fig. 22).

Elytra long, ca. 4 times longer than wide at humeri, slightly widening distally, with slender, equally developed primary costae; all interstices with double rows of small, mostly square obscured by pubescence cells; pubescence short and semierect. Tibiae and femoris straight, narrow; tarsomere 4 slightly widened, tarsomeres 1-2 with apical plantar pad (Fig. 22).

Aedeagus slightly asymmetric, with long, straight, narrow median lobe, conspicuously widened and incised in distal half and oblique apically, provided with paired dents and drop-like structure; phallobase constituting ca 0.2 length of median lobe (Figs 23-24).

Female. Similar to male, but eyes slightly smaller (Fig. 25). External genitalia with free coxites and valvifers; styli large, only ca. 1.2 times shorter than coxites; valvifers almost straight, ca. 1.3 times longer than coxites (Fig. 26).

Length: $6.1-8.1 \mathrm{~mm}$. Width (humerally): $1.5-2.1 \mathrm{~mm}$.

ETYMOLOGY. The name of the new species is derived from the Latin for "with a drop», alluding to the drop-like structure at the distal portion of its aedeagus.
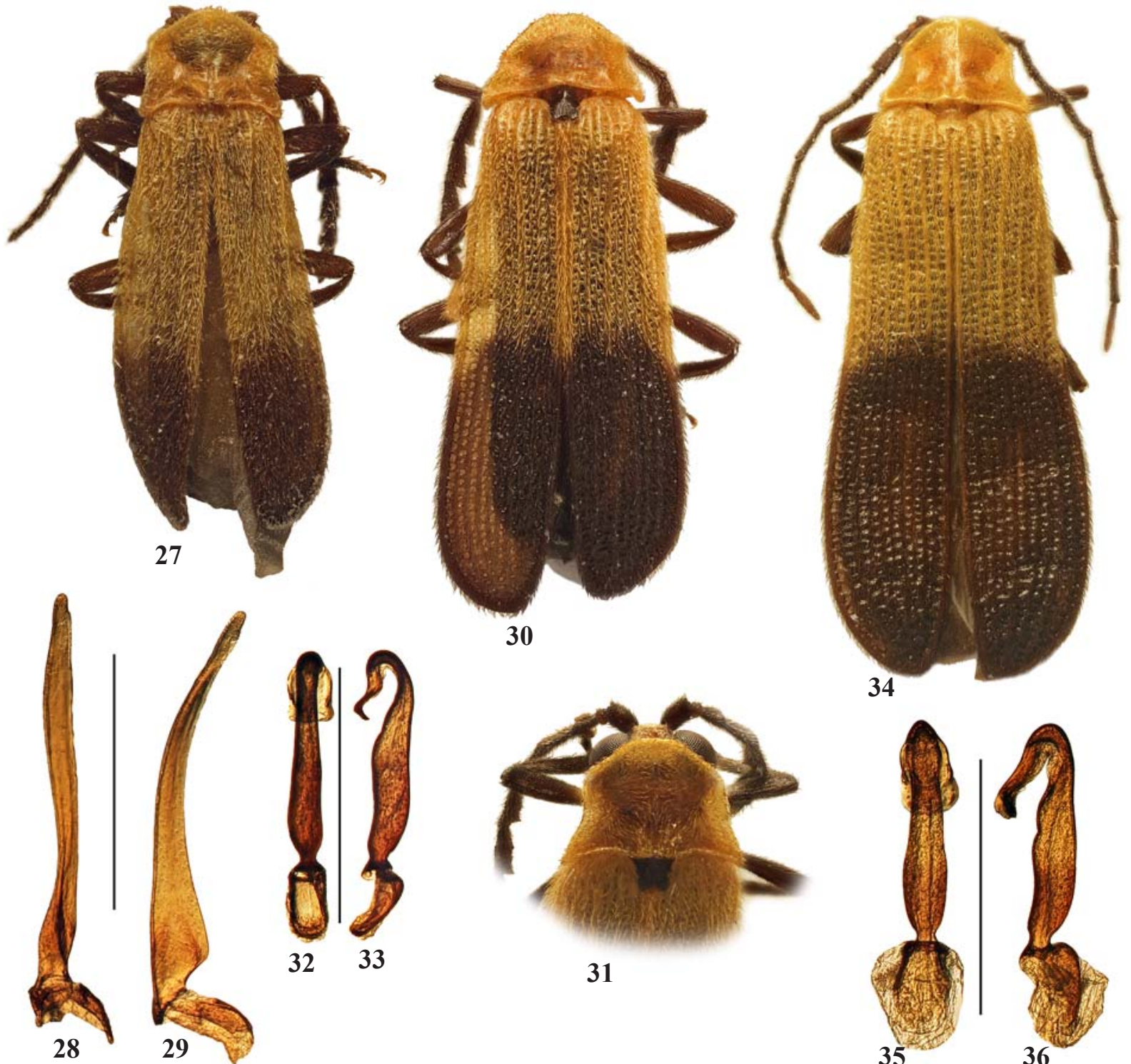

34

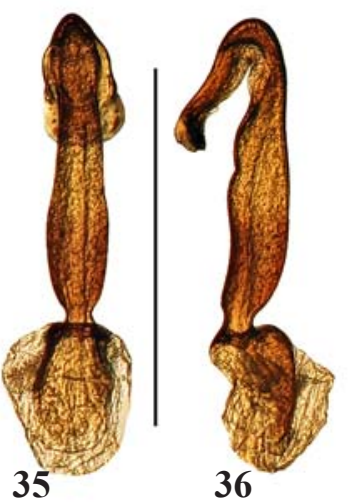

Figs 27-36. General view and aedeagi of Plateros, holotype males: 27-29 - P. gorongosus sp.n.; 30-33 - P. hamifer sp.n.; 34-36 P. hamulifer sp.n.; 27, 30, 34 - general view; 31 - head and pronotum; 28-29, 32-33, 35-36 - aedeagus; 27, 30-31, 34-35 - dorsal aspect; 28, 32 - ventral aspect; 29, 33, 36 - lateral aspect. Scale bars: $1.0 \mathrm{~mm}$.

Рис. 27-36. Общий вид и детали строения Plateros, голотипы, самцы: 27-29 - P. gorongosus sp.n.; 30-33 - P. hamifer sp.n.; 34-36 - P. hamulifer sp.n.; 27, 30, 34 - общий вид; 31 - голова и переднеспинка; 28-29, 32-33, 35-36 - эдеагус; 27, 30-31, 34 35 - сверху; 28, 32 - снизу; 29, 33, 36 - сбоку. Масштабные линейки: 1.0 мм. 
DIAGNOSIS. Plateros guttifer sp.n., being similar in habitus to a number of Plateros from the East African Rift (e.g., P. ochropterus (Gorham, 1883) from Ethiopia, P. ablutus (Bourgeois, 1908) from Kenya and Uganda, P. collarti (Pic, 1931) from the Ruwenzori), is quite unlike all of them in the structure of the median lobe of the aedeagus (Figs 22-24).

DISTRIBUTION. Known only from Rwanda.

\section{Plateros gorongosus Kazantsev, sp.n. Figs 27-29.}

MATERIAL: Holotype, $0^{7}$, Mozambique, Gorongosa N.P., $10.05^{\circ} \mathrm{S}, 34.15^{\circ}$ E, $10-12 . I I .2000$, J. Jones (ICM); paratype, + same label (ICM).

DESCRIPTION. Male. Dark brown to black; pronotum, scutellum and elytra, except at distal third, testaceous.

Vertex shining, with prominent deep round excavation behind antennal prominence. Eyes relatively large, interocular distance ca. 1.1 times greater than eye diameter. Labrum small, transverse, truncate anteriorly. Palps slender, ultimate palpomeres elongate, narrow, conspicuously narrowed distally and glabrous distally. Antennal sockets separated by minute lamina. Antennae dentate, attaining to elytral middle; antennomeres 3-5 broad, antennomeres 6-11 gradually narrowing distally; antennomere $3 \mathrm{ca} .1 .7$ times longer than antennomere 2 and ca. 1.3 times shorter than antennomere 4 ; antennomeres 3-11 with short semi-erect pubescence (Fig. 27).

Pronotum transverse, ca. 1.6 times as wide as long, almost straight basally and triangularly produced forward anteriorly, with slightly concave sides, acute posteriorly produced posterior and conspicuous blunt anterior angles; medially with obscure narrow longitudinal impression posteriorly. Mesothoracic spiracle small, hoodless, not protruding beyond coxa. Scutellum subquadrate, parallel-sided, medially feebly emarginate at apex (Fig. 27).

Elytra long, ca. 3 times longer than wide at humeri, parallelsided, with slender, primary costa 4 noticeably stouter in proximal half; all interstices with double rows of small subquadrate cells; dense pubescence short and semi-erect. Tibiae and femoris straight, relatively broad; tarsomeres 3-4 slightly widened, tarsomeres 1-2 with minute apical plantar pad (Fig. 27).

Aedeagus asymmetric, with elongate, narrow, almost straight, proximally flattened and broadly and angularly widened median lobe; phallobase constituting ca 0.2 length of median lobe (Figs 28-29).

Female. Similar to male, but eyes somewhat smaller and antennae shorter and less dentate.

Length: $6.2-6.3 \mathrm{~mm}$. Width (humerally): $1.6-1.7 \mathrm{~mm}$.

ETYMOLOGY. The new species is named after the type locality.

DIAGNOSIS. Plateros gorongosus sp.n. appears to be related to $P$. chirindanus (Kleine, 1933), from Zaire, Nyassa and Tanzania, but is separable by the uniformly testaceous pronotum and proximally broader median lobe of the aedeagus with angular edge (broadly rounded in $P$. chirindanus) (Figs 27-29).

DISTRIBUTION. East Africa (Mozambique).

\section{Plateros hamifer Kazantsev, sp.n.} Figs 30-33.

MATERIAL: Holotype, $\sigma^{7}$, Tanzania: E Usambara, Amani N.R., $5.05^{\circ} \mathrm{S}, 38.40^{\circ} \mathrm{E}, 1000 \mathrm{~m}, 20-22 . \mathrm{I} .2010$, M. Mityukhin leg. (ICM); paratype, + , same label, in copula (ICM).

DESCRIPTION. Male. Dark brown to black; antennomeres 10-11, pronotum, elytral proximal half (slightly more so along sides), front trochanters and front femurs basally orange testaceous.
Vertex shining, with shallow transverse impression and two small round excavations behind antennal prominence. Eyes large, interocular distance ca. 1.3 time shorter than eye diameter. Labrum small, transverse, almost truncate anteriorly. Palps slender, ultimate palpomeres elongate, narrow, parallelsided, flattened and glabrous distally. Antennal sockets separated by minute lamina. Antennae dentate, attaining to elytral two thirds; antennomere 3 ca. 1.2 times longer than antennomere 2 and ca. 1.8 times shorter than antennomere 4 ; antennomeres 3-11 with short semi-erect pubescence (Fig. 30).

Pronotum transverse, ca. 1.5 times as wide as long, trapezoidal, feebly bisinuate basally and triangularly produced forward anteriorly, with concave sides, acute, strongly produced postero-laterally posterior and conspicuous blunt anterior angles; medially with obscure longitudinal impression posteriorly and short rib anteriorly. Mesothoracic spiracle small, hoodless, not protruding beyond coxa. Scutellum subquadrate, parallel-sided, noticeably notched at apex (Fig. 30).

Elytra long, ca. 3.1 times longer than wide at humeri, almost parallel-sided, with slender, equally developed primary costae; all interstices with double rows of small roundish cells; dense pubescence short and semi-erect. Tibiae and femoris straight, narrow; tarsomeres 3-4 slightly widened, tarsomeres 1-2 with minute apical plantar pad (Fig. 30).

Aedeagus nearly symmetric, with elongate, straight proximally, provided with apical hook- or latch-like structure median lobe; phallobase constituting ca 0.3 length of median lobe (Figs 32-33).

Female. Similar to male, but eyes smaller and antennae slightly shorter and less dentate.

Length: 5.9-6.0 mm. Width (humerally): $1.6-1.7 \mathrm{~mm}$.

ETYMOLOGY. The name of the new species is derived from the Latin for «bearing a hook», alluding to the shape of its aedeagus.

DIAGNOSIS. Plateros hamifer sp.n., being of common in East Africa coloration pattern with almost half of elytra distally black (Fig. 30), is quite unlike other Plateros species in the structure of the aedeagus, with relatively broad and tapering distally median lobe, provided with apical hook- or latch-like structure (Figs 32-33).

DISTRIBUTION. East Africa (Tanzania).

\section{Plateros hamulifer Kazantsev, sp.n.} Figs 34-36.

MATERIAL: Holotype, $\sigma^{7}$, Malawi: Chitipa Distr., SE Chisenga, $10.2^{\circ} \mathrm{S}, 33.5^{\circ} \mathrm{E}, 1850 \mathrm{~m}, 19-21 . \mathrm{I} .2012$, N. Vikhrev (ICM).

DESCRIPTION. Male. Dark brown to black; pronotum, scutellum and elytral proximal half (slightly more so along sides) orange testaceous.

Vertex shining, with prominent deep round excavation behind antennal prominence. Eyes large, interocular distance 1.2 times shorter than eye diameter. Labrum small, transverse, medially emarginate anteriorly. Palps slender, ultimate palpomeres elongate, narrow, nearly parallel-sided, flattened and glabrous distally. Antennal sockets separated by minute lamina. Antennae dentate, attaining to elytral three fifths; antennomere 3 ca. 2.3 times longer than antennomere 2 and ca. 1.5 times shorter than antennomere 4 ; antennomeres 3-11 with short erect pubescence (Fig. 34).

Pronotum transverse, ca. 1.5 times as wide as long, bisinuate basally and triangularly produced forward anteriorly, with concave sides, acute, strongly produced posterior and conspicuous blunt anterior angles; medially with obscure longitudinal impression posteriorly. Mesothoracic spiracle small, hoodless, not protruding beyond coxa. Scutellum elongate, parallel-sided, triangularly emarginate at apex (Fig. 34). 
Elytra long, ca. 3.5 times longer than wide at humeri, noticeably widening distally, with slender, equally developed primary costae; all interstices with double rows of small subquadrate cells; pubescence relatively scarce, short and semi-erect. Tibiae and femoris straight, narrow; tarsomeres 3-4 slightly widened, tarsomeres 1-2 with minute apical plantar pad (Fig. 34).

Aedeagus nearly symmetric, with relatively robust, elongate, straight proximally median lobe, provided with apical hook- or latch-like structure; phallobase constituting ca 0.4 length of median lobe (Figs 35-36).

Female. Unknown.

Length: $6.3 \mathrm{~mm}$. Width (humerally): $1.7 \mathrm{~mm}$.

ETYMOLOGY. The name of the new species is derived from the Latin for «bearing a hook», alluding to the shape of its aedeagus.
DIAGNOSIS. Plateros hamulifer sp.n. is apparently close to $P$. hamifer sp.n., separable by the uniformly black antennae, orange testaceous scutellum and more robust and more curved blade of the 'hook'/'latch' structure of the median lobe of the aedeagus (Figs 34-36).

DISTRIBUTION. Recorded only in Malawi.

\section{Plateros hippocampus Kazantsev, sp.n.} Figs 37-39.

MATERIAL: Holotype, $O^{7}$, Congo (Brazzaville): Odzala National Park, $6.85^{\circ} \mathrm{S}, 37.67^{\circ} \mathrm{E}, 600 \mathrm{~m}, 10-15 . I I .1997$, S. Murzin \& V. Siniaev leg. (ICM).

DESCRIPTION. Male. Dark brown to black; antennomeres 2-3 and 9-11, pronotum, scutellum, elytra, pro- and mesocoxae, trochanters, femurs and tibiae basally testaceous.

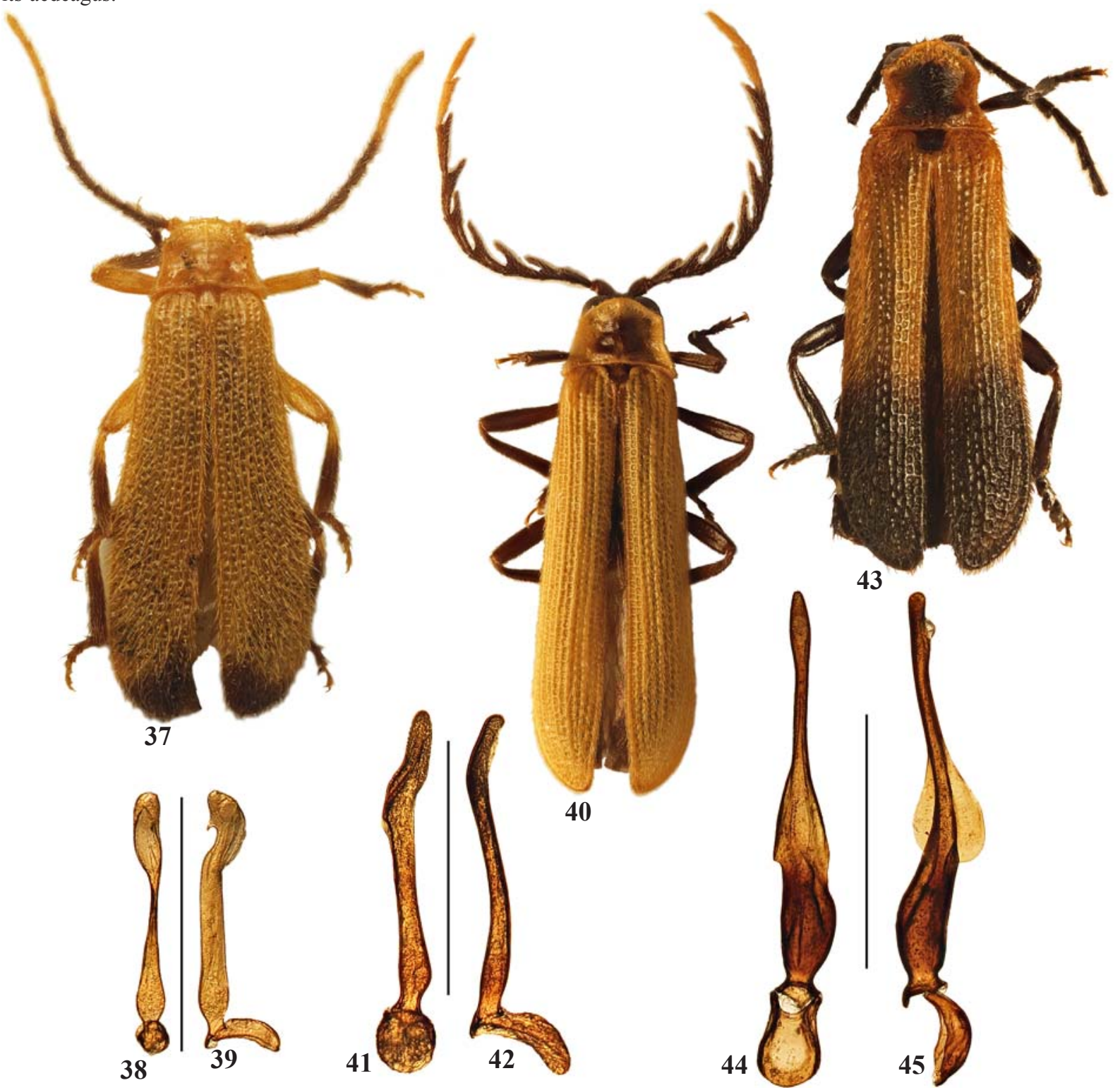

Figs 37-45. General view and aedeagi of Plateros, holotype males: 37-39 - P. hippocampus sp.n.; 40-42 - P. kuehnei sp.n.; 43-45 P. morogoroensis sp.n.; 37, 40, 43 - general view; 38-39, 41-42, 44-45 — aedeagus; 37-38, 40-41, 43-44 — dorsal aspect; 39, 42, 45 - lateral aspect. Scale bars: $1.0 \mathrm{~mm}$.

Рис. 37-45. Общий вид и детали строения Plateros, голотипы, самцы: 37-39 - P. hippocampus sp.n.; 40-42 - P. kuehnei sp.n.; 43-45 - P. morogoroensis sp.n.; 37, 40, 43 - общий вид; 38-39, 41-42, 44-45 - эдеагус; 37-38, 40-41, 43-44 - сверху; 39, 42, 45 — сбоку. Масштабные линейки: 1.0 мм. 
Vertex shining, with conspicuous transverse impression behind antennal prominence. Eyes relatively small, interocular distance ca. 1.1 times greater than eye diameter. Labrum small, transverse. Palps slender, ultimate palpomeres elongate, narrow, nearly parallel-sided, flattened and glabrous distally. Antennal sockets separated by minute lamina. Antennae dentate, attaining to elytral two thirds; antennomere 3 ca. 3.3 times longer than antennomere 2 and ca. 1.5 times shorter than antennomere 4; antennomeres 3-11 with long erect pubescence (Fig. 37).

Pronotum transverse, ca. 1.6 times as wide as long, bisinuate basally and rounded anteriorly, with slightly concave sides, acute posterior and blunt anterior angles; medially with obscure longitudinal impression posteriorly and narrow median rib anteriorly. Mesothoracic spiracle small, hoodless, not protruding beyond coxa. Scutellum subaquadrate, parallel-sided, broadly, but shallowly emarginate at apex (Fig. 37).

Elytra long, ca. 3.5 times longer than wide at humeri, slightly widening distally, with slender, equally developed primary costae; all interstices with double rows of small roundish cells; pubescence relatively long and semi-erect. Tibiae and femoris straight, narrow; tarsomeres 1-4 narrow, tarsomeres 1-2 without noticeable plantar pad (Fig. 37).

Aedeagus almost symmetric, with elongate, straight and dilated and hooked apically median lobe; phallobase constituting ca 0.25 length of median lobe (Figs 38-39).

Female. Unknown.

Length: $5.1 \mathrm{~mm}$. Width (humerally): $1.2 \mathrm{~mm}$.

ETYMOLOGY. The name of the new species is derived from the Latin for «seahorse», alluding to the shape of its aedeagus.

DIAGNOSIS. Plateros hippocampus sp.n. resembles $P$. afroguineensis Kazantsev, 2011, from Guinea, separable by the more robust and less hooked apically median lobe of the aedeagus (Figs 38-39).

DISTRIBUTION. West Africa (Congo).

\section{Plateros kuehnei Kazantsev, sp.n.} Figs 40-42.

MATERIAL: Holotype, $\mathrm{O}^{7}$, Kenya: West, Kakamega Forest N.R., 0.21,34 N, 34.51,39 E, 1600 m, Lichtfang, 1.VIII.2002, L. Kühne leg. (NME); paratype, $\odot$, Kenya: West, Kakamega Forest N.R., 0.21,34 N, 34.51,39 E, $1600 \mathrm{~m}$, Lichtfang, 10.X.2002, L. Kühne leg. (ICM).

DESCRIPTION. Male. Dark brown to black; antennomeres 10-11, broad pronotal margins and elytra bright testaceous.

Vertex shining, with prominent deep round impression behind antennal prominence. Eyes large, interocular distance 1.4 times shorter than eye diameter. Labrum small, transverse. Palps slender, ultimate palpomeres slightly longer than wide, obliquely truncate at apex. Antennal sockets separated by minute lamina. Antennae semi-flabellate, attaining to elytral two thirds; flabella of antennomeres 3-5 subequal in length to stem; antennomere $3 \mathrm{ca}$. 4.4 times longer than antennomere 2 and ca. 1.4 times shorter than antennomere 4 antennomeres $3-11$ with moderately long sub-erect pubescence (Fig. 40).

Pronotum transverse, ca. 1.7 times as wide as long, trapezoidal, concave basally and triangularly produced anteriorly, with slightly concave sides, acute, prominently produced posterior and noticeable blunt anterior angles; medially with obscure longitudinal impression posteriorly. Mesothoracic spiracle small, hoodless, slightly protruding beyond coxa. Scutellum subquadrate, slightly narrowing distally, rounded and feebly emarginate at apex (Fig. 40).
Elytra long, ca. 3.7 times longer than wide at humeri, parallel-sided, with equally developed strong primary costae; all interstices with double rows of small, mostly elongate cells; pubescence short and semi-erect. Tibiae and femoris straight, relatively narrow; tarsomeres 3-4 slightly widened, tarsomeres 1-2 with apical plantar pad (Fig. 40).

Aedeagus asymmetric, with elongate, bent above the middle and curved in apical third median lobe, phallobase constituting ca 0.3 length of median lobe (Figs 41-42).

Female. Similar to male, but larger, with smaller eyes and just strongly dentate antennae.

Length: 7.4-8.8 mm. Width (humerally): $1.7-2.2 \mathrm{~mm}$.

ETYMOLOGY. The new species is named after the collector of the type series.

DIAGNOSIS. In the shape of the aedeagus Plateros kuehnei sp.n. seems to be similar to P. flavus (Bourgeois, 1904), easily separable by the more elongate body and semiflabellate antennae, as well as by the less modified in the preapical portion median lobe of the aedeagus (Figs 40-42).

DISTRIBUTION. East Africa (Kenya).

\section{Plateros morogoroensis Kazantsev, sp. n.} Figs 43-45.

MATERIAL: Holotype, $\sigma^{7}$, Tanzania, env. Morogoro, $6.85^{\circ} \mathrm{S}$, $36.67^{\circ} \mathrm{E}, 600 \mathrm{~m}, 2-3$. XII.2015, N. Vikhrev (ICM).

DESCRIPTION. Male. Black; broad pronotal margins and elytral proximal two thirds reddish testaceous.

Vertex shining, with roundish impression behind antennal prominence. Eyes large, interocular distance 1.1 times shorter than eye diameter. Labrum small, transverse, almost truncate anteriorly. Palps slender, ultimate palpomeres elongate, obliquely narrowed distally and glabrous at apex. Antennal sockets separated by minute lamina. Antennae dentate; antennomere 3 short, ca. 5 times longer than antennomere 2 and ca. 1.1 times shorter than antennomere 4; antennomeres 3-8 with moderately long erect pubescence (Fig. 43).

Pronotum transverse, ca. 1.4 times as wide as long, almost straight basally and strongly triangularly produced anteriorly, with incised sides, acute posterior and pronounced blunt anterior angles; medially with obscure longitudinal impression posteriorly and short median rib anteriorly. Mesothoracic spiracle small, hoodless, slightly protruding beyond coxa. Scutellum subquadrate, slightly narrowing distally, truncate at apex (Fig. 43).

Elytra long, ca. 3.2 times longer than wide at humeri, parallel-sided, with equally developed primary costae; all interstices with double rows of small, mostly elongate roundish cells; pubescence short and semi-erect. Tibiae and femoris straight and broad; tarsomeres 3-4 widened, tarsomeres 1-2 with apical plantar pad (Fig. 43).

Aedeagus asymmetric, with elongate, bent in the middle and slightly dilated and pointed at apex median lobe, with medial paired earflap-shaped structure; phallobase constituting ca 0.2 length of median lobe (Figs 44-45).

Female. Unknown.

Length: $6.4 \mathrm{~mm}$. Width (humerally): $1.7 \mathrm{~mm}$.

ETYMOLOGY. The new species is named after the type locality.

DIAGNOSIS. Plateros morogoroensis sp.n. is quite similar to P. burgeoni (Pic, 1924), (Figs 1-2) known from the eastern Democratic Republic of the Congo and northern South Africa, but may be distinguished by the relatively more elongate antennomere 3 and noticeably wider proximally and apically median lobe of the aedeagus (Figs 43-45).

REMARKS. Tips of antennae in the holotype are missing. DISTRIBUTION. East Africa (Tanzania). 
Plateros nyungwensis Kazantsev, sp.n.

Figs 46-48.

MATERIAL: Holotype, $\sigma^{7}$, SW Rwanda, Nyungwe N.P., 1800 2000 m, 3-16.VII.2014, Sv. Kurbatova leg. (ICM); paratypes, 2 우, SW Rwanda, Nyungwe N.P., 1900-2100 m, 3-16.VII.2014, S. Kurbatov leg. (ICM).

DESCRIPTION. Male. Black; antennomeres 9-11, broad pronotal margins and elytra testaceous.

Vertex shining, with prominent antennal bulge. Eyes moderately large, interocular distance ca. 1.1 times greater than eye diameter. Labrum small, transverse, emarginate medially. Palps slender, ultimate palpomeres elongate, nearly parallel-sided, flattened and glabrous at apex. Antennal sockets separated by minute lamina. Antennae dentate, slightly reaching over elytral half elytral two thirds; antennomere 3 short, ca. 1.5 times longer than antennomere 2 and ca. 2.3 times shorter than antennomere 4; antennomeres 3-11 with short erect pubescence (Fig. 46).

Pronotum transverse, ca. 1.5 times as wide as long, almost straight basally and rounded anteriorly, with slightly concave sides, acute posterior and rounded blunt anterior angles; medially with obscure longitudinal impression posteriorly and short median rib anteriorly. Mesothoracic spiracle small, hoodless, not protruding beyond coxa. Scutellum subquadrate, slightly narrowing distally, rounded and slightly emarginate at apex (Fig. 46).

Elytra long, ca. 3.8 times longer than wide at humeri, widening distally, with slender, equally developed primary costae; all interstices with double rows of small, mostly elongate cells; pubescence short and semi-erect. Tibiae and femoris straight, narrow; tarsomeres 3-4 slightly widened, tarsomeres 1-2 with apical plantar pad (Fig. 46).

Aedeagus symmetric, with elongate, straight, narrow median lobe, widened distally, constricted before apex and
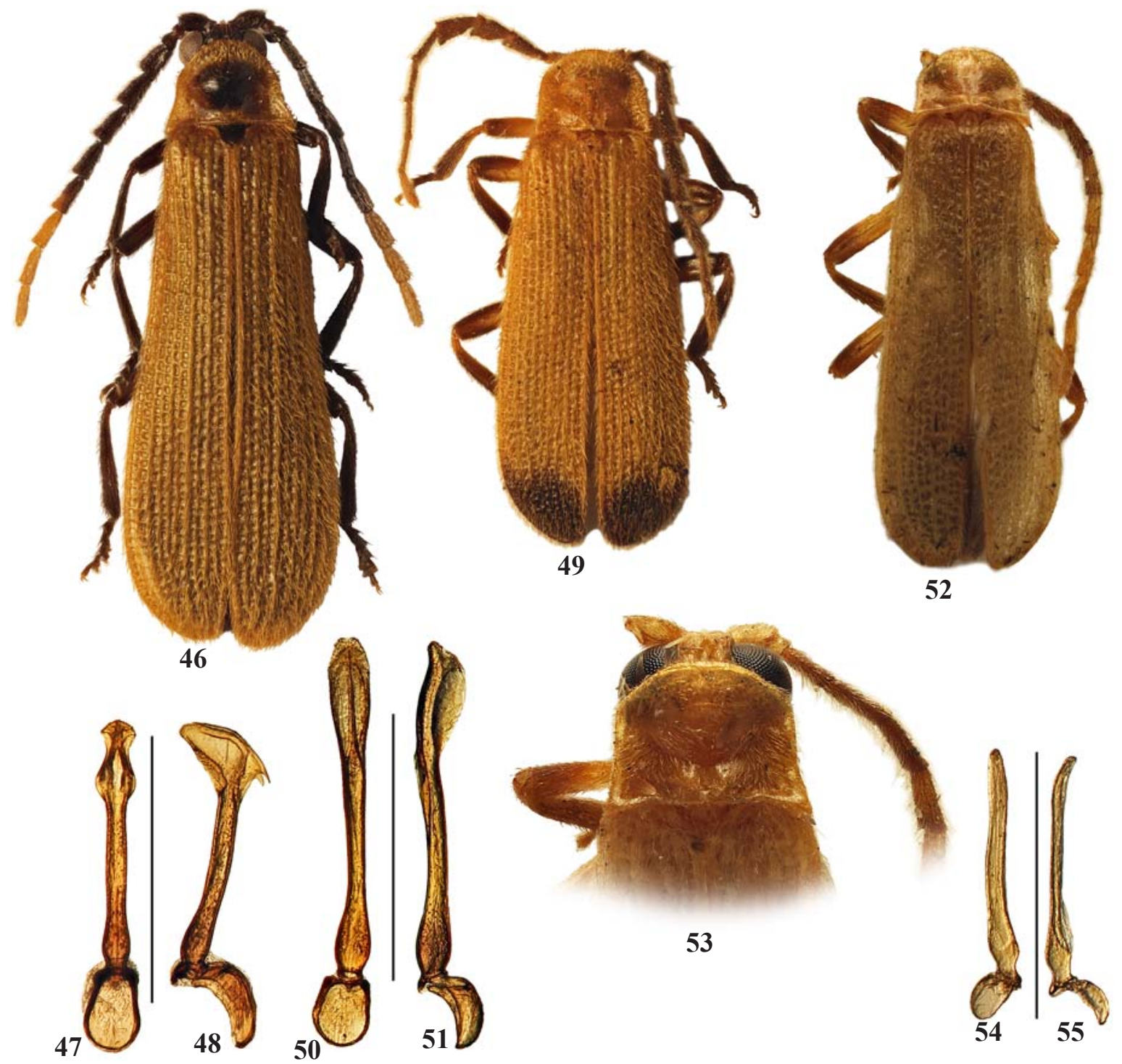

Figs 46-55. General view and aedeagi of Plateros, holotype males: 46-48 - P. nyungwensis sp.n.; 49-51 - P. odzalaensis sp.n.; 5255 - P. ogovensis sp.n.; 46, 49, 52 - general view; 53 - head and pronotum; 47-48, 50-51, 54-55 — aedeagus; 40-47, 49-50, 52-54 — dorsal aspect; 48, 51, 55 - lateral aspect. Scale bars: $1.0 \mathrm{~mm}$.

Рис. 46-55. Общий вид и детали строения Plateros, голотипы, самцы: 46-48 - P. nyungwensis sp.n.; 49-51 — P. odzalaensis sp.n.; 52-55 - P. ogovensis sp.n.; 46, 49, 52 - общий вид; 53 - голова и переднеспинка; 47-48, 50-51, 54-55 - эдеагус; 40-47, 49-50, 52-54 - сверху; 48, 51, 55 - сбоку. Масштабные линейки: 1.0 мм. 
dilated again and rounded at apex; apically provided with paired dents; phallobase constituting ca 0.3 length of median lobe (Figs 47-48).

Female. Similar to male, but eyes smaller and antennae slightly less dentate, with relatively longer antennomere 3 .

Length: $6.5-8.2 \mathrm{~mm}$. Width (humerally): $1.5-2.0 \mathrm{~mm}$.

ETYMOLOGY. Species is named after the type locality.

DIAGNOSIS. Plateros nyungwensis sp.n. may be placed near $P$. draco Kazantsev, 2005, from Liberia, but is easily distinguished by the short third antennomere, different coloration and relatively shorter and broader in distal part median lobe of the aedeagus (Figs 46-48).

DISTRIBUTION. Known only from Rwanda.

\section{Plateros odzalaensis Kazantsev, sp.n.} Figs 49-51.

MATERIAL: Holotype, $\sigma^{\top}$, Congo (Brazzaville): Odzala National Park, $6.85^{\circ}$ S, $37.67^{\circ}$ E, 600 m, 10-15.II.1997, S. Murzin \& V. Siniaev leg. (ICM).

DESCRIPTION. Male. Dark brown; head anteriorly, antennomeres 2 and 11, pronotum, scutellum, elytra, except at distal tenth, trochanters and femurs proximally testaceous.

Vertex shining, with longitudinal median impression behind antennal prominence. Eyes moderately large, interocular distance ca. 1.25 times greater than eye diameter. Labrum small, transverse. Palps slender, ultimate palpomeres slightly longer than wide, widened ditsally, flattened and glabrous at apex. Antennal sockets separated by minute lamina. Antennae dentate, attaining to elytral two thirds; antennomere $3 \mathrm{ca}$. 1.2 times longer than antennomere 2 and ca. 4.5 times shorter than antennomere 4; antennomeres 3-11 with long erect pubescence (Fig. 49).

Pronotum transverse, ca. 1.5 times as wide as long, feebly bisinuate basally and rounded anteriorly, with straight sides, acute posterior and rounded anterior angles; medially with obscure longitudinal impression posteriorly. Mesothoracic spiracle small, hoodless, not protruding beyond coxa. Scutellum subquadrate, slightly narrowing distally, rounded and emarginate at apex (Fig. 49).

Elytra long, ca. 3.1 times longer than wide at humeri, slightly widening distally, with slender, equally developed primary costae; all interstices with double rows of small roundish cells; pubescence short and semi-erect. Tibiae and femoris straight, moderately broad; tarsomeres 3-4 slightly widened, tarsomeres 1-2 with apical plantar pad (Fig. 49).

Aedeagus almost symmetric, with long, straight, narrow median lobe, slightly widened and curved in distal third; phallobase constituting ca 0.2 length of median lobe (Figs 50-51).

Female. Unknown.

Length: $6.3 \mathrm{~mm}$. Width (humerally): $1.7 \mathrm{~mm}$.

ETYMOLOGY. The new species is named after the type locality.

DIAGNOSIS. Plateros odzalaensis sp.n. resembles $P$. bonneviei (Pic, 1924), from the Democratic Republic of the Congo, differing by the more robust and deprived of an apical hook median lobe of the aedeagus (Figs 50-51).

DISTRIBUTION. Known only from Congo (Brazzaville) (West Africa)

\section{Plateros ogovensis Kazantsev, sp.n.} Figs 52-55.

MATERIAL: Holotype, $\sigma^{\top}$, Congo (Brazzaville): upper Ogove R., 16.II.1997, S. Murzin leg. (ICM).

DESCRIPTION. Male. Dark brown to black; head, antennomeres 1-2 and 7-11, pronotum, scutellum, elytra, trochanters and femurs, except distally, testaceous.
Vertex shining, with prominent round impression behind antennal prominence. Eyes moderately large, interocular distance ca. 1.4 times shorter than eye diameter. Labrum small, transverse. Palps slender, ultimate palpomeres conspicuously widened distally, rounded, flattened and glabrous at apex. Antennal sockets separated by minute lamina. Antennae flattened, feebly dentate, attaining to elytral three fourths; antennomere 3 ca. 3.5 times longer than antennomere 2 and ca. 1.3 times shorter than antennomere 4; antennomeres 3-11 with long erect pubescence (Fig. 52).

Pronotum transverse, ca. 1.5 times as wide as long, feebly bisinuate basally and rounded anteriorly, with slightly concave sides, acute posterior and noticeable blunt anterior angles; medially with obscure longitudinal impression posteriorly and short median rib anteriorly. Mesothoracic spiracle small, hoodless, not protruding beyond coxa. Scutellum subquadrate, narrowing distally, rounded at apex (Fig. 53).

Elytra long, ca. 3.6 times longer than wide at humeri, slightly widening distally, with slender, equally developed primary costae; all interstices with double rows of small roundish cells; pubescence short and semi-erect. Tibiae and femoris straight, moderately broad; tarsomeres 1-4 narrow, tarsomeres 1-2 without plantar pad (Fig. 52).

Aedeagus asymmetric, with elongate, almost straight, narrow median lobe, slightly curved near apex, with proximal location of opening; phallobase constituting ca 0.2 length of median lobe (Figs 54-55).

Female. Unknown.

Length: $4.7 \mathrm{~mm}$. Width (humerally): $1.1 \mathrm{~mm}$.

ETYMOLOGY. The new species is named after the type locality.

DIAGNOSIS. By the shape of its aedeagus Plateros ogovensis sp.n. may be placed near $P$. chirindanus (Kleine, 1933), from Nyassa and Congo (Zaire), differing by the shorter, straighter and less widened proximally median lobe (Figs 54-55).

DISTRIBUTION. Known only from Congo (Brazzaville) (West Africa).

\section{Plateros subulifer Kazantsev, sp.n.}

Figs 56-58.

MATERIAL: Holotype, $0^{7}$, E Gabon: Ogooué-Ivindo Prov., 7.7 km SW Makokou, Ivindo N.P., Ipassa Research Station, 0 $30^{\prime} 52^{\prime \prime}$ $\mathrm{N}, 12^{\circ} 48^{\prime} 21^{\prime \prime} \mathrm{E}, 480-540 \mathrm{~m}$, edge of secondary lowland rainforest, UV light trap, 23-24.VI.2016, D. Telnov leg. (NME).

DESCRIPTION. Male. Dark brown to black; head, antennomeres 1-2 and 10-11, pronotum, scutellum, elytra, except distal tenth, trochanters and femurs, except at distal fourth, testaceous.

Vertex shining, with round impression behind antennal prominence. Eyes large, interocular distance ca. 1.9 times shorter than eye diameter. Labrum small, transverse, straight anteriorly. Palps slender, ultimate palpomeres longer than wide, noticeably widened distally, oblique, rounded, flattened and glabrous at apex. Antennal sockets separated by minute lamina. Antennae sharply dentate, attaining to elytral two thirds; antennomere 3 ca. 5 times longer than antennomere 2 and ca. 1.2 times shorter than antennomere 4 ; antennomeres $3-$ 11 with moderately long semi-erect pubescence (Fig. 56).

Pronotum transverse, ca. 1.3 times as wide as long, bisinuate basally and rounded anteriorly, with slightly concave sides, acute posterior and pronounced blunt anterior angles; medially with obscure longitudinal impression posteriorly. Mesothoracic spiracle small, hoodless, not protruding beyond coxa. Scutellum subquadrate, parallel-sided, slightly emarginate at apex (Fig. 56) 
Elytra long, ca. 3.3 times longer than wide at humeri, parallel-sided, with slender, almost equally developed primary costae, only primary costa 4 noticeably raised in humeral fourth; all interstices with double rows of small roundish cells; pubescence short and semi-erect. Tibiae and femoris straight, narrow; tarsomeres 3-4 slightly widened, tarsomeres 1-2 with apical plantar pad (Fig. 56).

Aedeagus almost symmetric, with very long, straight, narrow median lobe, slightly bent apically in lateral aspect; opening with small, but noticeable paired dents; phallobase constituting ca 0.25 length of median lobe (Figs 57-58).

Female. Unknown.

Length: $5.9 \mathrm{~mm}$. Width (humerally): $1.4 \mathrm{~mm}$.

ETYMOLOGY. The name of the new species is derived from the Latin for «bearing a bodkin», alluding to the shape of its aedeagus.

DIAGNOSIS. Plateros subulifer sp.n. is similar to P. montivagus Kazantsev, 2005, both in general appearance and in the very narrow and straight median lobe of the aedeagus, differing by the more dentate antennae and lower location of the apical opening of the median piece of the aedeagus, provided with noticeable paired dents (Figs 56-58).

DISTRIBUTION. West Africa (Gabon).

\section{Plateros uluguruensis Kazantsev, sp.n. Figs 59-61.}

MATERIAL: Holotype, $\sigma^{\top}$, Tanzania: env. Morogoro, Uluguru Mts, $5.84593^{\circ} \mathrm{S}, 38.692^{\circ} \mathrm{E}, 853 \mathrm{~m}, 17 . \mathrm{IX} .2012$, D.I. Gavryushin leg. (ICM); paratype, + , Tanzania: E Usambara, Amani N.R., 5.05 S, 38.40 E, $1000 \mathrm{~m}, 20-22 . I .2010$, M. Mityukhin leg. (ICM).

DESCRIPTION. Male. Black; pronotum and elytra, except at distal third, reddish testaceous.

Vertex shining, with deep round impression behind antennal prominence. Eyes moderately large, interocular distance ca. 1.1 times greater than eye diameter. Labrum small, transverse. Palps slender, ultimate palpomeres elongate, nearly parallel-sided, flattened and glabrous at apex. Antennal sockets separated by minute lamina. Antennae semi-flabellate, attaining to elytral two thirds; flabella of antennomeres 4-8 subequal in length to stem; antennomere $3 \mathrm{ca} .5$ times longer than antennomere 2 and ca. 1.5 times shorter than antennomere 4; antennomeres 3-11 with long erect pubescence (Fig. 59).

Pronotum transverse, ca. 1.5 times as wide as long, feebly bisinuate basally and rounded anteriorly, with slightly concave sides, acute posterior and rounded blunt anterior angles; medially with obscure longitudinal impression posteriorly. Mesothoracic spiracle small, hoodless, not protruding beyond coxa. Scutellum subquadrate, slightly narrowing distally, almost truncate at apex (Fig. 59).

Elytra long, ca. 3 times longer than wide at humeri, slightly widening distally, with more or less equally developed primary costae; all interstices with double rows of small roundish cells; pubescence dense, short and semi-erect, obscuring reticulation. Tibiae and femoris straight, moderately broad; tarsomeres 3-4 slightly widened, tarsomeres 1-2 with apical plantar pad (Fig. 59).

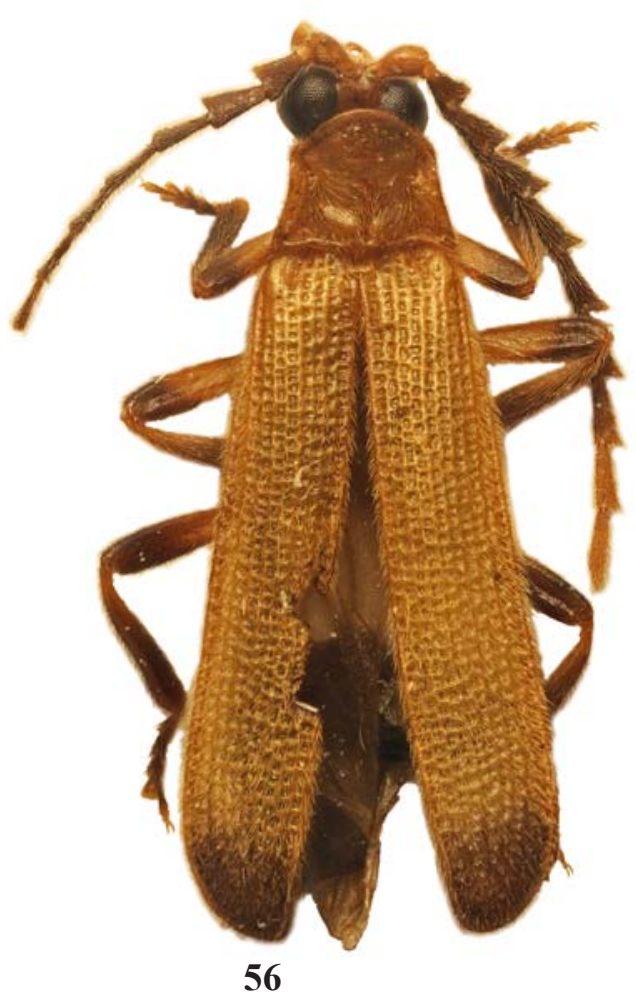

60

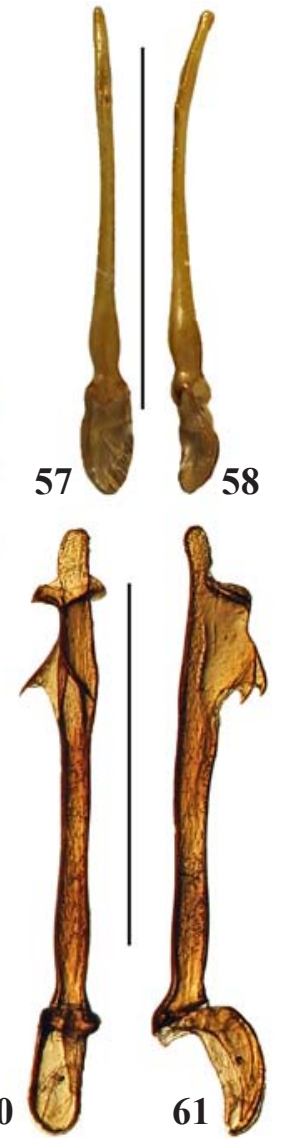

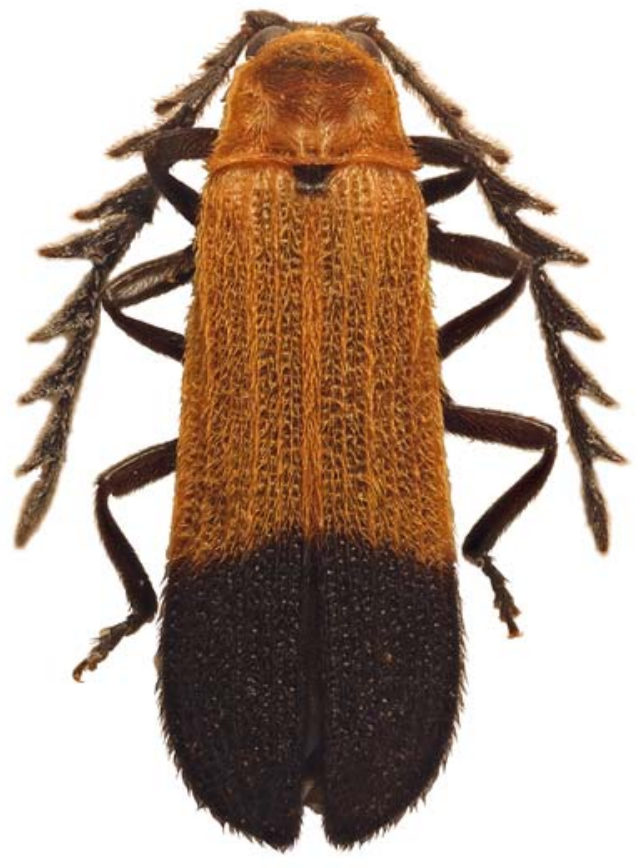

59

Figs 56-61. General view and aedeagi of Plateros, holotype males: 56-58 - P. subulifer sp.n.; 59-61 - P. uluguruensis sp.n.; 56, 59 general view; 57-58, 60-61 — aedeagus; 56-57, 59-60 — dorsal aspect; 58, 61 - lateral aspect. Scale bars: $1.0 \mathrm{~mm}$.

Рис. 56-61. Общий вид и детали строения Plateros, голотипы, самцы: 56-58 - P. subulifer sp.n.; 59-61 - P. uluguruensis sp.n.; 56-59 - общий вид; 57-58, 60-61 - эдеагус; 56-57, 59-60 - сверху; 58, 61 - сбоку. Масштабные линейки: 1.0 мм. 
Aedeagus slightly asymmetric, with long, straight, narrow median lobe, provided with bidentate structure around opening; phallobase constituting ca 0.25 length of median lobe (Figs 60-61).

Female. Similar to male, but eyes noticeably smaller and antennae just dentate.

Length: $6.8-7.1 \mathrm{~mm}$. Width (humerally): $1.8-1.9 \mathrm{~mm}$.

ETYMOLOGY. The new species is named after the type locality.

DIAGNOSIS. Plateros uluguruensis sp.n. resembles P. crucifer (Kazantsev, 2000), from the Democratic Republic of the Congo, but may be distinguished by the uniformly black antennae, uniformly orange testaceous pronotum and black distal third of the elytra, as well as by the more developed structures of the distal opening of the median lobe of the aedeagus (Figs 58-50).

DISTRIBUTION. East Africa (Tanzania).

The following new name is proposed to replace the existing younger homonym:

Plateros breveapis nom.n. pro Plateros breveapicalis (Pic, 1938): 157 (Planeteros, variation of P. atriventris Pic, 1922), from Kamerun, nec Plateros breveapicalis (Pic, 1931): 105 (Planeteros, variation of $P$. soppoensis Pic, 1922), from Congo.

\section{Checklist of Plateros Bourgeois, 1879 of} Africa

\section{Plateros Bourgeois, 1879}

Plateros Bourgeois, 1879: xix. Type species: Eros brasiliensis Lucas, 1857 (subsequsent designation by Zaragoza, 1999)

= Planeteros Gorham, 1883: 591. Type species: Planeteros ochropterus Gorham, 1883: 591 (by monotypy) ablutus Bourgeois, 1908: 275 (Planeteros). East Africa.

=asperatus Kleine, 1940: 892 (Planeteros)

=atricornis Pic, 1925: 186 (Planeteros)

=neavei Kleine, 1940: 893 (Planeteros) afroguineensis Kazantsev, 2011: 185. West Africa (Guinea). =guineensis Kazantsev, 1997: 11 (Planeteros), HN allouadi Bourgeois, 1908: 275 (Planeteros). East Africa. amaniensis Kazantsev, 2018, sp.n. East Africa (Tanzania). antennifer Kazantsev, 2011: 185. Congo (Zaire). =antennalis Kleine, 1930: 167 (Planeteros), HN arndti Kazantsev, 2000: 116 (Planeteros). Burundi. aurifer Kazantsev, 2018, sp.n. West Africa (Ghana). bayoni Pic, 1924: 162 (Planeteros). Uganda. bequaerti Kleine, 1930: 169 (Planeteros). Congo (Zaire). bicoloricornis Pic, 1922: 21 (Planeteros). «Africa». bicoloripes Pic, 1923: 74 (Planeteros). West Africa (Sierra Leone).

bilineatus Pic, 1931: 106 (Planeteros). Congo (Zaire). =gigas Kleine, 1940: 252 (Planeteros)

bonneviei Pic, 1924: 439 (Planeteros). Congo (Zaire). breveapicalis Pic, 1931: 105 (Planeteros). Congo (Zaire). breveapis Kazantsev, 2018, nom.n. West Africa (Kamerun). =breveapicalis Pic, 1938: 157 (Planeteros), HN burgeoni Pic, 1924: 439 (Planeteros). Congo (Zaire). =bredoi Kasantsev, 1997: 15 (Planeteros) chirindanus Kleine, 1933: 15 (Planeteros). East Africa(Nyassa), Congo (Zaire). =zairicus Kasantsev, 1997: 15 (Planeteros) collarti Pic, 1931: 106 (Planeteros). Congo (Zaire).

=salubris Kleine, 1940: 149 (Planeteros)

congoensis Kleine, 1930: 168 (Planeteros). Congo (Zaire). crucifer Kazantsev, 2000: 110 (Planeteros). Congo (Zaire). curtus Bourgeois, 1905: 194 (Planeteros). West Africa (Biafra).

davidensis Kazantsev, 2005: 242. South Africa.

dewittei Kazantsev, 2018, sp.n. West Africa (Democratic

Republic of the Congo).

draco Kazantsev, 2005: 241. West Africa (Liberia).

drymophilus Kazantsev, 2000: 111 (Planeteros). West Africa (Guinea)

eburneus Kazantsev, 2018, sp.n. West Africa (Cote d'Ivoire). escalerae Bourgeois, 1904: 194 (Planeteros). West Africa (Biafra).

=soppoensis Pic, 1922: 21 (Planeteros)

flavoapicalis Kleine, 1935: 109 (Planeteros). East Africa.

flavopictus Kazantsev, 1997: 12 (Planeteros). West Africa (Guinea).

flavus Bourgeois, 1904: 195 (Planeteros). West Africa (Biafra).

=atriventris Pic, 1922: (Planeteros)

flos Kazantsev, 2000: 111 (Planeteros). Congo (Zaire).

ganganicus Kazantsev, 1997: 14 (Planeteros). West Africa (Guinea).

gorongosus Kazantsev, 2018, sp.n. East Africa (Mozambique).

guttifer Kazantsev, 2018, sp.n. East Africa (Rwanda). hamifer Kazantsev, 2018, sp.n. East Africa (Tanzania). hamulifer Kazantsev, 2018, sp.n. East Africa (Malawi). helicopher Kazantsev, 2000: 114 (Planeteros). Congo (Zaire).

helicophilus Kazantsev, 2000: 115 (Planeteros). Congo (Zaire).

hippocampus Kazantsev, 2018, sp.n. West Africa (Congo). hospitus Kleine, 1940: 893 (Planeteros). Congo (Zaire). kuehnei Kazantsev, 2018, sp.n. East Africa (Kenya). lestoni Kazantsev, 2005: 241. West Africa (Ghana). menieri Kazantsev, 1997: 12 (Planeteros). West Africa (Guinea).

montiganganus Kazantsev, 2005: 243. West Africa (Guinea).

montivagus Kazantsev, 2005: 242. West Africa (from Guinea to Congo (Zaire)).

morogoroensis Kazantsev, 2018, sp.n. East Africa (Tanzania).

murzini Kazantsev, 1997: 16 (Planeteros). West Africa (Guinea).

nigricauda Bourgeois, 1910: 118 (Planeteros). East Africa. nigrithorax Pic, 1935: 447 (Planeteros). Congo (Zaire). nigriventris Pic, 1926: 118 (Planeteros). West Africa (Fernando Poo).

=bicoloripes Pic, 1924: 162 (Planeteros), HN

nyungwensis Kazantsev, 2018, sp.n. East Africa (Rwanda). ochropterus Gorham, 1883: 591 (Planeteros). East Africa (Abyssinia).

=africanus Bourgeois, 1883: 633 (Planeteros) odzalaensis Kazantsev, 2018, sp.n. West Africa (Congo). ogovensis Kazantsev, 2018, sp.n. West Africa (Congo). pennilongus Kazantsev, 2005: 244. East Africa (Abyssinia). 
=longipennis Pic, 1929: 2 (Planeteros), HN petrovi Kazantsev, 2000: 113 (Planeteros). West Africa (Guinea). postpustulatus Kleine, 1940: 894 (Planeteros). West Africa (Kamerun)

prominens Kleine, 1940: 895 (Planeteros). West Africa (Kamerun).

rectithorax Pic, 1922: 21 (Planeteros). Congo (Zaire). seminigrans Kazantsev, 1997: 14 (Planeteros). West Africa (Guinea).

sibutensis Pic, 1922: 21 (Planeteros). Central African Republic (Fort Sibut).

similis Kleine, 1933: 20 (Planeteros). Congo (Zaire)

=simillimus Kleine, 1930: 170 (Planeteros), HN smithsonianus Kazantsev, 2005: 241. West Africa (Liberia). subulifer Kazantsev, 2018, sp.n. West Africa (Gabon). terrier Kazantsev, 2000: 112 (Planeteros). West Africa (Guinea).

uluguruensis Kazantsev, 2018, sp.n. East Africa (Tanzania). ustipennis Fairmaire, 1887: 154. East Africa ('Uzagara'). zerchei Kazantsev, 2000: 117 (Planeteros). West Africa (Kamerun).

zumpti Kleine, 1940: 894 (Planeteros). East Africa.

ACKNOWLEDGEMENTS. It is my pleasant duty to express gratitude to Dr. P. Limbourg (Institut Royal de Sciences naturelles de Belgique, Bruxelles), Dr. D. Telnov (Entomological Society of Latvia, Riga), Dr. M. Hartmann (Naturkundemuseum, Erfurt), Dr. M. Balke(Zoologische Staatssammlung, München) and Ms. R. Müller (Transvaal Museum of Natural
History, Pretoria) through whose courtesy I was able to study the afrotropical Lycidae collections under their care. I also wish to thank D. Gavryushin, S. Kurbatov, Sv. Kurbatova, M. Mityukhin, S. Murzin and N. Vikhrev (all from Moscow) for the possibility to get access to the lycid material collected during their expeditions to Africa.

\section{References}

Bourgeois J. 1883. Lycides nouveaux ou peu connus du Musée civique de Gênes // Annali del Museo Civico di Storia Naturale di Genova. Vol.18. P.621-648.

Fairmaire L. 1887. Coléoptères des voyages de M. G. Revoil chez les Somalis et dans l'Intérieur du Zanquebar// Annales de la Société entomologique de France. Vol.6. No.6. P.69-186, 277-368, Pl. $1-3$.

Gorham H.S. 1883. Descriptions of Malacodermata in the Civic Museum of Natural History at Genoa // Annali del Museo Civico di Storia Naturale de Genova. Vol.18. P.591-597.

Kazantsev S.V. 1997. Sur le sous-genre Planeteros (Coleoptera, Lycidae) // Revue française d'Entomologie (N.S.). Vol.19. Nos.12. P.7-17.

Kazantsev S.V. 2000. To the knowledge of the African subgenus Planeteros of the genus Melaneros (Coleoptera, Lycidae) // Beiträge für Entomologie, Berlin. B.50. H.1. S.103-118.

Kazantsev S.V. 2005. Contribution to the knowledge of the genus Plateros (Lycidae, Coleoptera) // Russian Entomological Journal. Vol.13. No.4 (2004). P.237-244.

Kazantsev S.V. 2011. New and little known taxa of Platerotini, with a note on biogeography of the tribe (Lycidae, Coleoptera) // Russian Entomological Journal. Vol.20. No.2. P.151-187.

Kleine R. 1933. Pars 123: Lycidae. Coleopterorum Catalogus auspiciis et auxilio W. Junk editus a Schenkling. W. Junk, Berlin. $145 \mathrm{pp}$. 